IJMS 25 (2), 1-17 (2018)

How to cite this article:

Kang, H. (2018). An application of 'building blocks of competitive advantage' approach to the U.S. cereal market leaders. International Journal of Management Studies, 25(2), 1-17.

\title{
AN APPLICATION OF `BUILDING BLOCKS OF COMPETITIVE ADVANTAGE' APPROACH TO THE U.S. CEREAL MARKET LEADERS
}

\author{
HYUNGU KANG \\ College of Business Administration \\ Central Michigan University, U.S.A. \\ kang1h@cmich.edu
}

\begin{abstract}
In the strategic management field, the study of building and sustaining competitive advantage for businesses has been one of the most important research areas. Although there are various attempts to explain the processes of building and sustaining competitive advantage, it has continued to be a poorly defined and operationalized construct. This paper focuses on the application of a strategic analytical approach, "Building Blocks of Competitive Advantages", to analyze and compare the sources of competitive advantage for two market leaders in the U.S. breakfast cereal industry, Kellogg's and General Mills. Various literature were reviewed in order to gain an understanding of the industry, and the roles played by these companies. As expected, Kellogg's and General Mills have similar sources of competitive advantage, however, these companies have shown different ways of developing competitive advantage. This study was carried out in an attempt to stimulate efforts and provide direction on the conceptual development of the sources for competitive advantage.
\end{abstract}

Keywords: Building blocks of competitive advantage, Sources of competitive advantage, Internal strengths and weaknesses, U.S. Breakfast Cereal Market, Kellogg's, General Mills.

Received: 19/07/2018 Revised: 25/07/2018 Accepted: 23/05/2019 Published: 15/12/2019 


\section{Introduction}

As a fundamental component of businesses, building and sustaining a competitive advantage has continued to be one of the most important objectives for any enterprise (Barney, 1991; Porter, 1985). Competitive advantage is the leverage that a business has over its competitors (Barney, 1991; Porter, 1985). The impact of competitive advantage of a firm would allow for huge advantages over other firms, particularly when charging premium prices or lowering costs.

Therehave been numerous attempts to explain the processes of building and sustaining competitive advantages (Litman, 2000; Barney, 1991; Harvard Management Update, 2008; Doyle \& Wong, 1998; Sigalas, 2015; Ma, 1999; Sigalas \& Economou, 2013; Arbi, Bukhari, \& Saadat, 2017). Several strategy management research have examined the sources of competitive advantage in order to explain the key criteria of building and sustaining competitive advantages (Hill \& Jones, 2009; Mar, 2013; Olulade, 2014). However, there are still confusions surrounding the definition of the term "competitive advantage", within the context of business strategy (Arbi et al., 2017). This confusion and lack of clarity in the ideas that relates to the sources of competitive advantage have increased the strategic difficulty faced by managers when defining their competitive advantage.

There are many possible sources of competitive advantage. However, it is important that the chosen advantage provides value to the business. Porter (1980) suggested that the performance of a firm in a competitive environment is due to its unmatched competitive advantage in that particular environment. Moreover, a firm can create and sustain a competitive advantage in any industry. The author further asserts that the value a firm produces for its customers will need to be higher than the cost that is required by the firm to produce the value. Furthermore, it is suggested that a firm's competitive advantage grows from these value creation activities.

Hill, Schilling, and Jones (2016) identified the four key value creation criteria to explain the sources of competitive advantage. The four building blocks of competitive advantage are superior efficiency, quality, innovation, and customer responsiveness (Hill \& Jones, 2009; Hill et al., 2016). These building blocks allow a company to differentiate its product offerings to provide more utility to customers and/or lower its cost structure. 
The breakfast cereal manufacturing industry is currently one of the most competitive industries in the U.S. There are many companies, large and small, that compete both within the United States as well as globally in this industry. For most of these companies, the manufacturing of breakfast cereal has been their main objective. Nevertheless, these companies have also competed in other sub-food industries, such as snacks and crackers, that helped increase their competitive edge and sales.

The purpose of this study is to analyze the sources of competitive advantage for the two market leaders in the U.S. breakfast cereal manufacturing industry, Kellogg's and General Mills, based on the four building blocks of competitive advantage. Subsequently, the sources of competitive advantage are compared between the two companies.

\section{Research Method}

This study employed an exploratory research approach that investigates the similarities and differences of the sources of building competitive advantage in different companies. In this study, an extensive literature review was conducted on the four building blocks of competitive advantage, and the sources of competitive advantage across different companies.

Specifically, this study combined the findings from real cases involving two competitors' competitive advantage, into theoretical and conceptual findings from literature to evaluate and compare different paths of building competitive advantages. Various resources and literature were compiled to analyze and compare the two companies' sources of competitive advantage which included industry trade magazines, company's website, announcements, news articles, case studies, and various websites describing the topics of competitive advantages of Kellogg's and General Mills, and the U.S. breakfast cereal industry as a whole.

\section{Literature Review}

\section{Building Blocks of Competitive Advantage}

There are four factors that help a company build and sustain competitive advantage: Efficiency, Quality, Innovation, and Customer 
responsiveness (Hill \& Jones, 2009; Hill et al., 2016). These are the generic building blocks of competitive advantage that any company can adopt, regardless of its industry, or the products and services it provides. Each factor is the result of the way the various value-chain activities within an enterprise is performed. By performing valuechain activities to achieve superior efficiency, quality, innovation, and customer responsiveness, a company can (1) differentiate its product offerings, and hence offer more value to its customers, and (2) lower its cost structure.

Although these factors seem independent from each other, they are interrelated. For example, superior quality can lead to superior efficiency, while innovation can enhance efficiency, quality and customer responsiveness.

\section{Superior Efficiency}

A business is a transformation process of inputs to outputs. Inputs are the basic factors of production such as material, labor, time, equipment, capital, and technological skills and know-how. Outputs are the goods and services that the business produce. The more efficient a company is, the fewer the inputs that are required to produce a given output. Efficiency helps the company attain a competitive advantage by lowering the cost structure. Superior efficiency is viewed from the perspective of the producers in an industry. It is one of the major sources of competitive advantage as it allows companies to increase the productivity of its employees and capital, and thus reducing its cost structure (Hill et. al., 2016).

Moreover, efficiency can help a company attain a competitive advantage by providing a lower cost structure. Superior efficiency is viewed from the perspective of the producers in an industry.

\section{Superior Quality}

Quality is commonly viewed as excellent product attributes and superior reliability. Agus (2008) has indicated that quality is viewed as a fundamental source for firms to develop competitive advantage. High quality increases the utility to customers, which allows businesses to manage the flexibility of their pricing. In contrast to superior efficiency, superior quality is viewed from the perspective of the customers. 
A product is a collection of various attributes. The attributes of any product includes the form, features, options, performance, durability, reliability, style, and design of the product. A product is said to have superior quality when the attributes of the product is perceived by the customer as those with greater value than the attributes of products sold by rivals (Hill et. al., 2016).

The impact of high quality products on competitive advantage is twofold (Garvin, 1984; Crosby, 1980): (1) The supply of high-quality products would increase its value (utility) to customers which provides the opportunity for companies to charge a higher price for their products. (2) Greater efficiency and lower unit costs associated with reliable products of high-quality would improve competitive advantage (Mokhtar \& Yusoff, 2008). When products are reliable, the employee's time will not be wasted making defective products or providing substandard services. Therefore, the lesser the time spent fixing the mistakes, the higher it will be for employee productivity that would lead to lower unit costs.

\section{Superior Innovation}

Innovation refers to the act of creating new products or processes (Hill et al., 2016; Lipinski, 2012). There are two main types of innovation: product innovation and process innovation. Product innovation is the development of products that are new to the world or have superior attributes than the existing products. Process innovation is the development of a new process to produce products and deliver them to customers. Product innovation creates value through the development of new products and improving current existing products that customers perceive as having more value. This allows the option for companies to charge a higher price. Process innovation often allows a company to create more value by lowering production costs. For example, Toyota's lean production system has helped boost employee productivity, giving Toyota a cost-based competitive advantage.

In the long run, innovation of products and processes will essentially be an important building block for developing competitive advantage in any businesses. Moreover, competition between companies are viewed as a process driven by innovation in both products and processes. 


\section{Superior Customer Responsiveness}

If a company does a better job than their competitors in identifying and satisfying customer needs, wants and cravings, therefore, this source of competitive advantages is regarded as superior customer responsiveness. Customer responsiveness allows a company to customize its offerings, improve response time, and provide superior service (Hill et al., 2016). Customers will then attribute more value to the products, creating a competitive advantage based on differentiation. Improving the quality of a company's product offering is consistent with achieving customer responsiveness as the newly developed products will have features that may not be present in existing products. Additionally, another factor that may stand out is the need to customize goods and services to the unique demands of individual customers or customer groups.

An aspect of responsiveness to customers that has drawn increasing attention is customer response time, which is the time that it takes for goods to be delivered or a service to be performed (Stalk \& Hout, 1990). Other sources of enhanced responsiveness to customers are superior design, superior service, and superior after-sales service and support.

\section{U.S. Breakfast Cereal Industry and Market Leaders}

\section{Overview of U.S. Breakfast Cereal Industry}

The cereal manufacturing industry is responsible for producing readyto-eat cereal that is made from various raw materials such as rice, wheat, corn and other wheat sources (Masterson, 2016). In addition to ready-to-eat cereals, this industry is also responsible for creating hot cereals such as oatmeal. Each product is designed and produced by companies in such a manner to reach their target consumers. Generally, consumers can be differentiated into many consumer types, for instance the general population such as young children to a niche consumer such as those who are nutritionally concerned and gluten-free. While these products are uniquely designed to serve the end consumers, they should first go through the primary customer of the cereal manufacturing industry. The primary customers, or buyer, for this industry are supermarkets, convenience stores, wholesalers, and exporters (Masterson, 2016). These buyers are responsible in helping the cereal industry to achieve their end goal through the 
supply of products to customers by providing the necessary display space and advertisements of the product.

This industry has been around for decades and is often a staple product in many consumers' homes, however, as most consumers have regularly purchased their products, the market has become saturated. In other words, the cereal manufacturing industry has reached their full potential in the market. This saturation has caused the industry to reach its maturity level. Furthermore, sales in this industry have started to decrease in the last couple years (Masterson, 2016). This market saturation and maturity has subsequently led to a fierce competition within the industry, particularly among the leading companies such as General Mills, Kellogg's Company and Post Holding, Inc. (Hofbauer, 2014). The declining sales have become a major strategic issue that needs to be overcome within the cereal manufacturing industry. Moreover, the declining market has forced the major players to re-evaluate their strategies and research the strategic reasoning behind this downturn.

\section{General Company Information of Kellogg's and General Mills}

Kellogg's. Kellogg's initially started in 1898 when two brothers, W.K. Kellogg and Dr. John Harvey Kellogg accidentally flaked their corn that was intended to make granola (Kellogg's Our History, 2016). While they did not successfully create granola, they created the first ever Kellogg's Corn Flakes, which was the beginning of the Kellogg's brothers' entrepreneurial venture (Kellogg's Our History, 2016). This venture began as a cereal manufacturing company, but would soon become a global enterprise that competes in the breakfast food industry, as well as the snack industry.

In early 1906, W.K. Kellogg dissolved his partnership with his brother and started his own business called the Battle Creek Toasted Corn Flake Co. that was based in Battle Creek, Michigan (Kellogg Co., 2016). After a year of operation, the company suffered its first setback when the main building burned to the ground. They were able recovered from this quickly and within six months, they were back to full operation. By 1909, W.K. Kellogg sued his brother over the use of the name Kellogg and when the rights were granted back to him, he renamed the company to Kellogg Toasted Corn Flake Company, which would eventually be renamed again as Kellogg's Company in 1922, due to the variety of other products that they offered. In 1914, Kellogg's made its first venture into the international market 
by opening a manufacturing plant in Canada (Kellogg's Our History, 2016). In the next few decades, the company continued to grow their product line as well as their international ventures. During that time, they created one of their most successful brands, Special K which was targeted to their adult customers. In 1970, Kellogg expanded their brand by purchasing Eggo Waffles and Fearn International. The company continued its exponential growth by creating new cereals and products, and became the world's leading producer of ready to eat cereals by the early 1990's, controlling over 40 percent of market share (Kellogg Co., 2016).

In the late 90 's, a major portion of the market share was dominated by their rival, General Mills. This company was able to reduce the margin to four percent between the two companies, which was a drastic change from the 30 percent gap just four years before. Despite this aggressive competition, Kellogg was able to maintain and recapture their dominance in the industry by refocusing their advertising on successful and well-established brands, and increasing their globalization efforts (Kellogg Co., 2010, 2016). To further strengthen and diversify the brand, Kellogg's acquired multiple companies in the early millennium including: Worthington Food Inc., Kashi Company, Keebler, Kraft's fruit snacks line, and a few other international companies (Kellogg Co., 2010). The purchases of these companies and brands allowed Kellogg's to further expand the company's competitiveness into the snack industry. During the expansion phase, Kellogg purchased Pringles from Proctor \& Gamble in 2012 that helped Kellogg achieve nearly double their global snack presence (Brown, 2012; Kellogg Co., 2016). Today, the company has started to focus on areas such as snacks, with an interest on innovation (Watrous, 2016). Furthermore, to address the issue of decreasing demand for cereal, the company has invested in boosting their brand's image and providing new products from other successful brands. Overall, innovation has become the prime objective for Kellogg's to stay competitive in the cereal and snack manufacturing industry.

General Mills. General Mills started as a flour mill in 1866 by Cadwallader Washburn in Minneapolis, Minnesota (General Mills, Inc., 2015). It was formally known as the Minneapolis Milling Company, and had brewed a rivalry with Charles Pillsbury, another miller that was working in the same region during the time. Despite 
their differences, they came together to create an association for the Midwest to help improve the overall quality of their wheat, which eventually became the finest wheat in the United States.

The companies continued to create quality flour up until 1924, when they finally entered the cereal manufacturing industry with their first cereal, Wheaties (General Mills, Inc., 2015). After starting to venture into new products and establishing a few mills, the company was renamed. By 1928, the company formally known as Minneapolis Milling Company became General Mills. From this point, the growth of General Mills accelerated. Within months, they had operations in 16 states and had become the world's largest flour-mill company.

By the 1930s, the company was creating ready-to-eat cereals such as Kix and Cheeiroats, now referred to as Cheerios, and also created Bisquick that were used in baking (General Mills Inc., 2015). While still maintaining their main objective on baking which led to the creation of the Betty Crocker brand, the company started to advertise their Wheaties brands as the infamous 'Breakfast of Champions' by using athletes as their brand ambassadors. During this time, advertisements on television were growing and General Mills started to place multiple ads to help create a brand image for which through these efforts, they came in second behind Kellogg's in market share (General Mills Inc., 2015).

General Mills had also suffered various setbacks in some ventures. In the 1940s, the company had attempted to enter the electronics market to make an unrelated diversification effort, which unfortunately failed. However, the president shifted General Mills' strategy to include the snack industry and soon acquired Morton Foods, Inc., followed by numerous other smaller snack brands. The snacks industry was not the only diversification that General Mills was interested, they soon found themselves in the restaurant business after purchasing Red Lobster. The restaurant lines were successful and would eventually include Olive Garden and China Coast. These restaurant chain would split and become their own successful companies adjacent to General Mills, by the name Darden Restaurants, Inc. (General Mills Inc., 2015).

In 1989, General Mills conducted business outside of the United States by partnering with Nestle to enter the European market. They shifted their focus back to creating convenience foods such as different versions of Hamburger Helper, Betty Crocker rice, and Yogurt To Go. 
In 2001, General Mills made one of their largest acquisitions, Pillsbury, a company that was growing similarly to them. This purchase placed them behind Kraft and ConAgra Foods as a domestic food company that owned many more brands such as Progresso, Refrigerator Dough, and Haagen-Dazs.

Through the continued acquisition of other smaller companies, they overcame tough times when the economy faced financial troubles. Their success was due to the strong demand from the people who were eating food at home and needed low cost convenience meals which General Mills mostly provided. While most companies struggled during the financial crisis, General Mills was able to continue to thrive and even grow its international businesses.

\section{Sources of Competitive Advantage of Kellogg's and General Mills}

\section{Efficiency}

Efficiency has become one of the sources of competitive advantage for Kellogg's. While they have not always been the most efficient with their finances, they have begun to refocus their objectives on efficiency. Recently, they have initiated the 'Kellogg's Project $K^{\prime}$ that works to provide an overall cost cut in efforts to maximize their efficiency (Tahiri, 2015). This initiative allowed them to commence consolidation efforts to trim away any unnecessary costs. Lately, they have changed their supply chain operations by shutting down their distribution centers and have shifted from direct delivery to stores, towards a wholesaler operations system in efforts to reach their goals (Sturtz, 2017). This is a drastic change for the company, however, this will simplify the operations while cutting down costs of the workforce and unnecessary facilities.

On the other hand, efficiency is General Mills' most concerning weakness as they are unfortunately struggling in many efficiency aspects. Their main inefficiency is their high debt level they have incurred, where their debt to equity ratio for 2016 was 1.59 percent (General Mills, Inc., 2017). This measure indicates that they have incurred more debt than investments. Another aspect of inefficiency that was observed in General Mills is their rapid growth. General Mills has been growing at a rapid pace as can be seen from their historic information, however while they keep growing, the products 
and acquisitions domestically have been lacking the focus needed to attract customers and being competitive in the global market.

\section{Quality}

Many factors such as rainfall, drought, humidity, temperature, sunlight, frost, soil conditions, harvesting equipment and chemicals are a part of the environment which will influence the quality of the raw materials that are used to manufacture cereal. Once the cereal has been manufactured, other quality concerns such as safety, sanitation, humidity, storage, and shelf-life must be considered. Consistency in product quality is a priority for the end consumer and Kellogg's brand has been a reliable producer in ensuring consistency of quality. The brand has received global recognition for their outstanding ability to achieve this. Another factor that is supportive of their quality is their marketing. This has helped them achieve their brand identity.

Quality is one of the core sources of competitive advantage in General Mills. This is influenced by their popular brand names, recognition of packaging by customers and numerous product lines that are offered. Furthermore, it has been a core advantage since day one when General Mills worked with Pillsbury as a flour mill to increase the quality of their winter flour (General Mills Inc., 2017). In addition to providing quality product, the company has continuously cared for their employees through the acceptance of diversity in the work place, improvement of corporate responsibility, and participation in volunteering efforts. This shows their dedication and commitment to not only their consumers, but also towards the corporate environment and employees.

\section{Innovation}

Kellogg's has once used innovation as their competitive advantage, however, it is currently considered as a weakness for the overall brand. Kellogg's has been slow to adapt to the consumers' needs and have not released any major or innovative products. Nevertheless, Kellogg's has embraced this weakness and is working hard to use it as their primary internal strength. According to Watrous (2016), Kellogg's has shifted the company to refocus on their product development for both their cereal and snack industry. In addition, 
the Project K initiative has allocated their profits from the efficiency movement to invest into the re-branding of products that emphasizes overall innovation (Tahiri, 2015).

Innovation has always been a core competitive advantage source to General Mills. This is observed from their history as they were able to grow from a local flour mill to a giant global retailer. They are knowledgeable to understand and identify the industries that are key to diversify their portfolio and the companies they should acquire to increase their brand image. General Mills tends to cater to the needs of their consumers by creating food products that are unique and delicious, as well as providing the diverse products for baking and cooking. Hence, the company continues to believe that innovation goes beyond their products and demand, and it is also shown in their efforts for sustainability (General Mills Inc., 2017).

\section{Responsiveness to Customers}

Responsiveness to customer needs is considered as a weakness for Kellogg's, for which they have been working to address. The company has been struggling to reach their target audiences for some time and with the increase in substitution breakfast options, they are trying hard to expand their businesses to cater to the demands of customers. Not only are their products lacking the convenience factor most consumers want, the company is slowly losing the millennial customers almost entirely (Darby, 2017). Therefore, they are taking the millennials head on by bringing back some of their packaging from the 90's to exploit the opportunities from their childhood memories. Moreover, as they also know that the millennials prefer to eat cereal as a snack, they should take full advantage and start innovating their marketing and products to cater to that demand.

As highlighted in innovations, responsiveness to the consumers' needs is always at the forefront of General Mills' strategy. This became a huge concern to General Mills as the sales of their cereals continued to decline. In the 2016 company's annual report, General Mills re-emphasized the need to focus on the consumer by initiating the Consumers First Strategy (General Mills Inc., 2017). This strategy applies a four steps procedure to guide the overall business plan. These steps include: focus on the core, focus on long-term investments, continue to invest and acquire companies that concentrate on these 
core products, and finally, work on the timeliness and responsiveness to the market (General Mills Inc., 2017). While responsiveness to customers is a huge internal strength, it was always going to be difficult to maintain and would not always guarantee success. This is especially true with the overall current demand as it shifts away from their core segment of cereal.

\section{Summary and Comparison of Sources of Competitive Advantages}

Both companies are notable examples of firms that have withstood the test of time and have continuously adapted to industry-wide changes. As previously stated, Kellogg's and General Mills are quite similar in their business scope, but have each formed their own competitive advantage and distinct competencies while successfully navigating the breakfast cereal industry.

The four factors of competitive advantage (efficiency, quality, innovation, and customer responsiveness) offer a company the ability to differentiate its product offerings, offer more value to its customers, and lower its cost structure. While each factor stands individually in terms of competitive advantage, they are interrelated. Each factor could affect the other.

While these companies are quite similar with regards to the products they sell, the buyers and suppliers they need, and the market in which they are trying to reach, the companies are essentially different, particularly in the way they utilize their corporate strategies to reach their goals. This study concludes that they are essentially opposites in terms of strengths and weaknesses for their competitive advantage sources. Kellogg's weaknesses lie in innovations and responsiveness to the customers, as these factors are both strengths to General Mills. The only shared attribute between these companies is that both the companies are able to maintain a high-quality image that is brought about by their brand name and recognition.

While both companies have the same competitive advantage in brand image, brand loyalty, and global perspectives, they each compete differently to gain the top market share. Kellogg focuses on breakfast and marketed it as the 'best way to start the day'. They have also 
placed special emphasis on the ingredients they use and how these ingredients benefit the consumer. While General Mills feels the same way about these aspects, General Mills' major focus as a brand is how they can help provide conveniences to the consumer. Their products are revolved around ways to make all foods accessible to improve the consumer's life. For instance, they have created box mixes for cakes and Hamburger Helper to help simplify the tasks and steps during meal-time preparations.

The cereal manufacturing industry has been proven to be a difficult industry to manage and operate successfully. It has been suggested that the difficulty that lies within this industry is not only due to the current economy and demand, but also the overall competitiveness of the industry, including competition between suppliers (within the industry). Furthermore, there are other external factors, such as the increase in regulatory compliance and the healthy substitution products which have recently gained popularity, that have flooded the already established cereal industry.

While these make it difficult for new entrants to exist in the industry, it does not deter the established brands such as Kellogg's and General Mills. However, the evolution of the industry affects the company's strategy on key concepts and innovation to maintain current profits and competitive edge. Specifically, they have been impacted by the need for the convenience of on-the-go foods and the increasing health initiative. Despite these setbacks, both brands have refocused their core products and the overall image. They can work to reverse the effects. These companies may be experiencing many external threats, but each company can use their unique competitive advantage to address these issues as opportunities. It is in the best interest for each of these companies to start investing in more innovative ideas and focus on their efficiencies by narrowing down on their core products that they already know will be successful. Moreover, these companies should concentrate on attracting millennials by re-branding cereal as a hassle-free breakfast through eliminating the need for milk or creating an entirely new cereal-based substitute product. However, the priority should be on convenience and health awareness. The cereal industry will continue to remain as a dominant food industry across the globe. Therefore, it is important that each of these companies maintain their quality image and competitive edge. 
In an attempt to explain the processes of building and sustaining competitive advantage within the context of strategic management and planning, this study provides a concise conceptual framework that is based on four core sources of competitive advantage: efficiency, quality, innovation, and customer responsiveness. In theory, any company can adopt the generic building blocks of competitive advantage, regardless of the industry or the products and services it provides.

\section{References}

Arbi, K., Bukhari, S., \& Saadat, Z. (2017). Theoretical framework for taxonomizing sources of competitive advantage. Management Research \& Practice, 9(4), 48-60.

Agus, A. (2008). Quality management and profitability linkage: Does the length of QM adoption act as the moderating variable? International Journal of Management Studies, 15 (Bumper Issues), $1-23$.

Barney, J. (1991). Firm resources and sustained competitive advantage. Journal of Management, 17(1), 99-120.

Brown, A. (2012, February 15). Kellogg Grabs Pringles for \$2.7B, Diamond Foods Loses Out. Retrieved February 6, 2018, from https://www. forbes.com/sites/abrambrown/2012/02/15/kellogg-to-buypringles-for-2-7-billion/\#1e70067f670f.

Crosby, P. B. (1980). Quality is free, New York: Mentor.

Darby, L. (2017, March 9). The Real Reason Millennials Aren't Eating Cereal for Breakfast. Retrieved May 03, 2018, from http://www. gq.com/story/the-real-reason-millennials-arent-eating-cerealfor-breakfast.

Garvin, D. (1984). What does product quality really mean? Sloan Management Review, 26, 25-44.

General Mills, Inc. (2017). General Mills 2017 Annual Report. Retrieved May 03, 2018, from http://investors.generalmills.com/2017interactive-annual-report/HTML1/default.htm.

General Mills, Inc. (2015). In J. P. Pederson (Ed.), International Directory of Company Histories (Vol. 166). Farmington Hills, MI: St. James Press. Retrieved May 03, 2018, from http://bi.galegroup.com/ global/article/GALE I I2501319186.

Harvard Management Update. (2008, February 27). The building blocks of strategy. Retrieved March 18, 2018, from https://hbr. org/2008/02/the-building-blocks-of-strateg?autocomplete=true. 
Hill, C., \& Jones, G. (2009). Strategic management theory: An integrated approach, 9th ed., South-Western Cengage Learning.

Hill, C., Schilling, M., \& Jones, G. (2016). Strategic management theory: An integrated approach, 12th ed., South-Western Cengage Learning.

Hofbauer, R. (2014, August). Hot and cold cereal - US - August 2014. Retrieved January 30, 2018, from https://store.mintel.com/hotand-cold-cereals-us-august-2014.

Kellogg Co. (2010). In T. Grant (Ed.), International directory of company histories (Vol. 110). Detroit: St. James Press. Retrieved February 3, 2018 from http://bi.galegroup. com/global/article/ GALE\%7C I2501313606/8c394030fd8c7e883c23217997068dca?

Kellogg Co. (2016). Our history. Retrieved February 6, 2017, from https:// www.kelloggs. com/en_US/who-we-are/our-history.html/.

Kellogg Co. (2017). Kellogg Company 2016 Annual Report. Retrieved from http://investor. kelloggs.com/ /media/Files/K/KelloggIR/Annual\%20Reports/kellogg-2016-ar-10-k.PDF.

Lipinski, J. (2012). Knowledge stickiness, knowledge management, and their impact on firm level competitive advantage. International Journal of Management Studies, 19(2), 1-13.

Litman, J. (2000). Genuine assets: Building blocks of strategy and sustainable competitive advantage. Strategic Finance, 82(5), 3742.

Ma, H. (1999). Creation and preemption for competitive advantage. Management Decision, 37(3), 259-266.

Mar, A. (2013, April 29). 6 Sources of Competitive Advantage. Retrieved March 29, 2018, from https://business.simplicable.com/ business/new/6-sources-of-competitive-advantage.

Masterson, R. (2016, July). Cereal production in the US. Retrieved March 2, 2018 from IBISWorld Database.

Mokhtar, S. \& Yusoff, R. (2008). The impact of process quality measurement on financial performance of market oriented firms, International Journal of Management Studies, 19 (Bumper Issue), 115-130.

Olulade, D.A. (2014, July 23). 12 Best Sources of Sustainable Competitive Advantage in Business, Retrieved March 15, 2018 from https:// www.linkedin.com/pulse/201407 23185841-260783246-12-bestsources-of-sustainable-competitive-advantage-in-business.

Porter, M. (1980). Competitive strategy. New York: The Free Press.

Sigalas, C. (2015). Competitive advantage: The known unknown concept. Management Decision, 53(9), 2004-2016. 
Sigalas, C., \& Economou, V. (2013). Revisiting the concept of competitive advantage: Problems and fallacies arising from its conceptualization. Journal of Strategy and Management, 6(1), 6180.

Stalk, G., \& Hout, T. M. (1990). Competing against time, New York: Free Press.

Sturtz, K. (2017, May 1). Kellogg to close Cicero distribution center; number of jobs affected unclear. Retrieved April 20, 2018, from https:// www.syracuse.com/news/index.ssf/ 2017/02/kellogg_to_close_ cicero_distribution_center_number_of_jobs_affected_unclear. html.

Tahiri, A. (2015, February 24). 5 Things Kellogg Company's Management Wants You to Know. Retrieved April 20, 2018, from https:// www.fool.com/investing/general/ 2015/02/24/5-things-kelloggcompanys-management-wants-you-to.aspx.

Watrous, M. (2016, February 12). Snacks 'An area of Weakness' for Kellogg. Retrieved February 6, 2018, from https://www. foodbusinessnews.net/articles/7497-snacks-an-area-ofweakness-for-kellogg. 